Jurnal Penelitian Karet, 2012, 30 (2) : 65 - 74

Indonesian J. Nat. Rubb. Res. 2012, 30 (2) : 65 - 74

\title{
EVALUASI PENGUJIAN LANJUTAN KLON KARET IRR SERI 120-140
}

\author{
Further Trial Evaluation of IRR 120-140 Series Rubber Clones
}

\author{
AIDI-DASLIN \\ Balai Penelitian Sungei Putih, Pusat Penelitian Karet \\ PO BOX 1415 Medan 20001 Sumatera Utara
}

Diterima tgl 21 Maret 2012 / Disetujui tgl 12 Juli 2012

\begin{abstract}
Activities of breeding program and rubber selection have been conducted in phases, starting from progenies selection, promotion plot and preliminary trials, then followed by further and adaptation trials. In preliminary trials, some potential genotypes as latex yielding with good secondary characteristics were obtained. In order to get more information, 17 selected genotypes derived from preliminary trial and registered as clones IRR 120 - 140 were tested in further trial in Sungei Putih Experimental Garden. The trial was conducted in 1997 and arranged in a randomized block design. Observation were made on the following parameters: dry rubber yield twice a month, girth size starting two years old, bark thickness and latex vessels at five years old, physiology of latex flow, attack intensity of Colletotrichum, Oidium, Corynespora leaf fall diseases and other characters. The results showed that clones IRR 132 and IRR 133 indicated best performance as latex yielders with good secondary characters. Average dry rubber yield $(\mathrm{kg} / \mathrm{ha} / \mathrm{yr})$ over eight tapping years showed that clone IRR $132(2,088 \mathrm{~kg})$ and IRR $133(2,006 \mathrm{~kg})$ was 15 - 20\% higher than $P B$ $260(1,739 \mathrm{~kg})$. GIrth size at four years old ranged from 42.8 to $43.6 \mathrm{~cm}$ with increment before tapping $7.1-10.9 \mathrm{~cm} / \mathrm{yr}$ and after tapping $3.0-3.8 \mathrm{~cm} / \mathrm{yr}$. Average virgin bark thickness was $6.5-6.7 \mathrm{~mm}$, classified as resistant to Colletotrichum, Oidium, and Corynespora leaf fall diseased. Clones IRR 131 and IRR 140 were promising to develop as timber and latex yielders (wood volume total $0.99-1.03 \mathrm{~m}^{3} /$ tree), dry rubber yield of both clones $(\mathrm{kg} / \mathrm{ha} / \mathrm{yr})$ ranged from 1,610 to 1,638 $\mathrm{kg}$.
\end{abstract}

Keywords : Hevea brasiliensis, further trial, clones of IRR 120-140 series

\begin{abstract}
Abstrak
Program pemuliaan dan seleksi tanaman karet dilakukan secara bertahap dari mulai seleksi progeni, uji plot promosi dan pendahuluan serta uji lanjutan dan adaptasi. Dari hasil uji pendahuluan telah dihasilkan beberapa genotipe yang potensial sebagai penghasil lateks serta memiliki sifat-sifat sekunder penting yang baik. Untuk mendapatkan informasi yang lebih luas, sebanyak 17 genotipe terpilih dari uji pendahuluan yang diregistrasi menjadi klon IRR seri 120 - 140 diuji pada tahap lanjutan di lokasi kebun percobaan Sungei Putih. Percobaan dibangun pada tahun 1997, menggunakan rancangan acak kelompok. Pengamatan dilakukan terhadap parameter berikut : produksi karet kering dua kali sebulan, lilit batang mulai umur dua tahun, tebal kulit murni dan jaringan pembuluh lateks pada umur lima tahun, fisiologi aliran lateks, intensitas serangan penyakit gugur daun Colletotrichum, Oidium, dan Corynespora serta karakter sekunder lainnya. Dari hasil evaluasi, IRR 132 dan IRR 133 merupakan klon yang memiliki penampilan terbaik sebagai klon penghasil lateks dan memiliki sifat sekunder yang baik. Rata-rata produksi karet kering $(\mathrm{kg} / \mathrm{ha} / \mathrm{th})$ selama delapan tahun penyadapan menunjukkan bahwa klon IRR $132(2.088 \mathrm{~kg})$ dan IRR $133(2.006$ $\mathrm{kg}), \quad 15$ - 20\% lebih tinggi daripada PB 260 (1.739 kg). Ukuran lilit batang pada umur empat tahun berkisar 42,8-43,6 cm dengan rata-rata pertambahan sebelum penyadapan $7,1-10,9 \mathrm{~cm} /$ th dan setelah penyadapan $3,0-3,8 \mathrm{~cm} /$ th. Rata-rata tebal kulit murni berkisar 6,5-6,7 mm, tergolong resisten terhadap penyakit gugur daun Colletotrichum, Oidium, dan Corynespora. Klon IRR 131 dan IRR 140 sesuai dikembangkan sebagai penghasil lateks dan
\end{abstract}


kayu (volume kayu total $0,99-1,03 \mathrm{~m}^{3} / \mathrm{ph}$ ), dengan produksi karet kering $\mathrm{kg} / \mathrm{ha} / \mathrm{th}$ berkisar $1.610-1.638 \mathrm{~kg}$.

Kata kunci: Hevea brasiliensis, pengujian lanjutan, klon IRR seri 120-140

\section{PENDAHULUAN}

Pengembangan komoditas karet sebagai bagian dari pembangunan subsektor perkebunan ditujukan untuk meningkatkan pendapatan devisa negara melalui pengembangan industri perkebunan karet yang efisiensi dan berdaya saing tinggi. Oleh karena itu sasaran penelitian karet harus dapat menyiapkan teknologi tepat guna yang dapat mendukung kinerja dan kesinambungan industri perkaretan nasional. Klon unggul merupakan salah satu komponen teknologi terpenting dalam meningkatkan produktivitas kebun dan efisiensi usaha. Penanaman klon-klon karet unggul penghasil lateks tinggi akan menekan biaya (harga) pokok sehingga diperoleh keuntungan yang lebih besar.

Kemajuan pemuliaan (breeding progress) dalam perakitan klon karet unggul sangat tergantung kepada tersedianya potensi dan sumber keragaman genetik. Penyiapan populasi dasar sebagai sumber keragaman dilakukan secara terus-menerus melalui kegiatan persilangan buatan, yang kemudian diikuti dengan seleksi progeni serta berbagai tahapan pengujian di lapangan. Genotipe terpilih dari populasi F1, selanjutnya dievaluasi pada tahap uji plot promosi dan uji pendahuluan. Klon-klon terpilih kemudian dievaluasi pada pengujian lanjutan dan pengujian adaptasi (Aidi Daslin, 2005). Melalui tahapan seleksi yang dilakukan dalam jangka panjang dan sistematis tersebut, sampai saat ini telah banyak dihasilkan klon-klon unggul harapan yang lebih produktif, diantaranya adalah klon IRR 104, IRR 112, dan IRR 118 dan telah dilepas untuk penanaman komersial (Woelan et al., 2005; Aidi-Daslin et al., 2009).

Evaluasi yang dilakukan pada uji pendahuluan (UP/01/93) memperlihatkan sejumlah genotipe memiliki potensi hasil lateks dan kayu yang tinggi (Suhendry, 2002). Nomor-nomor terpilih telah diregis- trasi kedalam klon IRR seri 120 - 140. Untuk mendapatkan data yang lebih luas, material tersebut diuji pada tahap uji lanjutan. Artikel ini merupakan laporan hasil evaluasi pengujian lanjutan klon IRR seri 120 - 140 (percobaan nomor :UL/14/97).

\section{BAHAN DAN METODE}

Pengujian klon dibangun pada tahun 1999 di lokasi kebun percobaan Balai Penelitian Sungei Putih. Bahan penelitian yang diuji sebanyak 17 klon terdiri atas IRR 122, IRR 123, IRR 127, IRR 129, IRR 131, IRR 132, IRR 133, IRR 134, IRR 136, IRR 137, IRR 138, IRR 139, IRR 140, IRR 141, IRR 142, IRR 143, IRR 144. Lokasi pengujian memiliki topografi datar, ketinggian tempat sekitar 54 meter dpl, jenis tanah Ultisol dengan tekstur lempung liat berpasir dan rata-rata curah hujan $1.962 \mathrm{~mm}$ per tahun. Percobaan di lapangan menggunakan Rancangan Acak Kelompok, ukuran plot 5 baris x 10 pohon (50 pohon/plot) dan jarak tanam $5 \times 4 \mathrm{~m}$ dengan klon pembanding PB 260. Pengamatan dilakukan terhadap pertumbuhan lilit batang, tebal kulit, potensi volume kayu, produksi karet kering, jaringan pembuluh lateks, serta berbagai sifat fisiologi aliran lateks. Untuk menghitung volume kayu digunakan rumus yang dikembangkan oleh Wan Razali Mohd et al., (1983). Pengamatan hasil karet kering $(\mathrm{g} / \mathrm{p} / \mathrm{s})$ dilakukan dua kali sebulan menggunakan sistem sadap $\mathrm{S} / 2$ d3. Pengamatan jaringan pembuluh lateks pada umur lima tahun dengan cara mengambil contoh kulit pada ketinggian $150 \mathrm{~cm}$ dari tanah (Gomez et al., 1972). Sifat fisiologi aliran lateks diamati pada umur delapan tahun mengacu kepada metode Milford et al., (1969). Intensitas serangan penyakit gugur daun Oidium, Colletotrichum dan Corynespora diamati pada umur 5 dan 8 tahun dan dihitung berdasarkan rumus yang dikembangkan oleh Pawirosoemardjo (1990).

\section{HASIL DAN PEMBAHASAN}

\section{Pertumbuhan Lilit Batang}

Data pertumbuhan lilit batang pada masa tanaman belum menghasilkan (TBM) dan tanaman menghasilkan (TM) tertera 
pada Tabel 1. Beberapa klon yang diuji memiliki pertumbuhan lilit batang lebih jagur dibandingkan dengan klon PB 260.

Pada Tabel 1 dapat dilihat klon yang memiliki ukuran lilit batang paling jagur sampai umur empat tahun adalah IRR 131 $(48,4 \mathrm{~cm})$ dan IRR $140(46,3 \mathrm{~cm})$, klon yang tergolong moderat yaitu IRR $132(43,6 \mathrm{~cm})$, IRR 133 (42,8 cm), IRR 134 (43,8 cm), IRR $136(44,8 \mathrm{~cm})$ IRR $138(43,2 \mathrm{~cm})$, dan IRR $144(41,4 \mathrm{~cm})$. Pertambahan lilit batang klon yang diuji pada masa TBM memperlihatkan variasi yang besar, dengan kisaran 6,4 - 11,6 $\mathrm{cm} /$ th. Klon yang memiliki pertumbuhan yang cepat pada masa TBM memiliki laju pertambahan lilit batang lebih dari $11 \mathrm{~cm} /$ th (Aidi-Daslin, 2005). Pada masa TM, kisaran pertambahan lilit batang klon yang diuji sampai umur 13 tahun bervariasi antara $2,5-4,9 \mathrm{~cm}$. Klon yang memiliki pertumbuhan paling jagur setelah disadap adalah IRR 131 (4,7 cm/th) dan IRR 140 (4,9 cm/th).

\section{Potensi Kayu}

Pemanfaatan kayu karet pada saat ini berkembang secara luas, baik untuk bahan baku industri perabotan maupun jenis papan partikel. Untuk mendukung kebutuhan industri kayu, maka seleksi klon tidak hanya menghasilkan klon unggul sebagai penghasil lateks tetapi juga klon-klon penghasil lateks-kayu, sehingga dapat meningkatkan produktivitas lahan maupun pendapatan pekebun. Beberapa nomor dari klon harapan IRR seri 120 - 140 memiliki potensi kayu yang cukup tinggi (Tabel 2), dengan kisaran rata-rata volume kayu log (kayu bebas cabang) antara 0,07 - 0,19 $\mathrm{m}^{3}$ / ph, volume kayu kanopi antara yaitu 0,18 $0,87 \mathrm{~m}^{3} / \mathrm{ph}$ dan volume kayu total antara $0,25-1,03 \mathrm{~m}^{3} / \mathrm{ph}$. Klon yang memiliki volume kayu total tertinggi adalah IRR 131 $\left(1,03 \mathrm{~m}^{3} / \mathrm{ph}\right)$, menyusul IRR $140 \quad(0,99$ $\left.\mathrm{m}^{3} / \mathrm{ph}\right)$ dan IRR $138\left(0,79 \mathrm{~m}^{3} / \mathrm{ph}\right)$ dibanding dengan PB $260\left(0,35 \mathrm{~m}^{3} / \mathrm{ph}\right)$. Seluruh klon seri IRR yang diuji menghasilkan volume

Tabel 1. Ukuran lilit batang dan laju pertumbuhan klon karet IRR seri 120 - 140

Table 1. Girth size and growth of IRR 120 - 140 rubber series clones

\begin{tabular}{|c|c|c|c|c|c|c|}
\hline \multirow{2}{*}{$\begin{array}{l}\text { Klon } \\
\text { Clones }\end{array}$} & \multicolumn{4}{|c|}{$\begin{array}{c}\text { Lilit batang }(\mathrm{cm}) \text { pada umur (thn) } \\
\text { Girth }(\mathrm{cm}) \text { in age }(\mathrm{yr})\end{array}$} & \multicolumn{2}{|c|}{$\begin{array}{c}\text { Pertambahan lilit batang }(\mathrm{cm} / \mathrm{th}) \\
\text { Girth increment }(\mathrm{cm} / \mathrm{yr})\end{array}$} \\
\hline & 2 & 3 & 4 & 5 & $\begin{array}{c}\text { TBM } \\
\text { Immature }\end{array}$ & $\begin{array}{c}\text { TM } \\
\text { Mature }\end{array}$ \\
\hline IRR 122 & 17,6 & 32,4 & 39,4 & 42,1 & 8,2 ( 98) & $2,5(76)$ \\
\hline IRR 123 & 18,1 & 30,2 & 36,2 & 38,8 & $6,9(82)$ & 3,1 ( 94) \\
\hline IRR 127 & 16,4 & 30,4 & 36,9 & 39,0 & 7,5 ( 89) & $2,7(82)$ \\
\hline IRR 129 & 17,4 & 31,9 & 36,9 & 41,6 & $8,1(96)$ & $3,7(112)$ \\
\hline IRR 131 & 21,1 & 39,7 & 48,4 & 55,8 & $11,6(138)$ & 4,7 (142) \\
\hline IRR 132 & 16,6 & 34,2 & 43,6 & 51,3 & 10,9 (130) & $3,0(91)$ \\
\hline IRR 133 & 18,6 & 28,6 & 42,8 & 49,8 & $7,1(85)$ & $3,8(115)$ \\
\hline IRR 134 & 16,6 & 32,8 & 43,8 & 49,3 & 10,9 (130) & $3,1(94)$ \\
\hline IRR 136 & 16,4 & 37,6 & 44,8 & 51,7 & $11,6(138)$ & $3,0(91)$ \\
\hline IRR 137 & 14,4 & 27,4 & 33,4 & 36,3 & $7,3(87)$ & 4,3 (130) \\
\hline IRR 138 & 17,7 & 33,4 & 43,2 & 50,0 & 10,8 (129) & $4,0(121)$ \\
\hline IRR 139 & 12,4 & 22,9 & 29,1 & 31,5 & $6,4(76)$ & $3,4(103)$ \\
\hline IRR 140 & 18,8 & 32,8 & 46,3 & 51,5 & 11,2 (133) & $4,9(148)$ \\
\hline IRR 141 & 11,1 & 16,9 & 23,0 & 35,6 & $6,8(81)$ & 3,2 ( 97) \\
\hline IRR 142 & 15,5 & 30,4 & 38,4 & 40,7 & $8,4(100)$ & $3,4(103)$ \\
\hline IRR 143 & 16,2 & 30,2 & 36,0 & 40,1 & 8,0 ( 95) & 3,5 (106) \\
\hline IRR 144 & 16,1 & 32,0 & 41,4 & 43,6 & 9,2 (110) & $2,8(85)$ \\
\hline PB 260 & 12,7 & 29,5 & 41,7 & 46,8 & $8,4(100)$ & $3,3(100)$ \\
\hline
\end{tabular}

TBM : tanaman belum menghasilkan (immature), TM : tanaman menghasilkan (mature)

Angka dalam kurung adalah persentase terhadap PB 260 (Figures in brackets are percentage of PB 260) 
Tabel 2. Potensi kayu karet klon IRR seri 120 - 140 pada umur 13 tahun Table 2. Rubber wood potency of clones IRR 120 - 140 series at 13 years old

\begin{tabular}{cccc}
\hline $\begin{array}{c}\text { Klon } \\
\text { Clones }\end{array}$ & $\begin{array}{c}\text { Volume kayu log }\left(\mathrm{m}^{3} / \mathrm{ph}\right) \\
\text { Log wood volume }\left(\mathrm{m}^{3} / \text { tree }\right)\end{array}$ & $\begin{array}{c}\text { Volume kayu } \\
\text { kanopi }\left(\mathrm{m}^{3} / \mathrm{ph}\right) \\
\text { Canopy wood } \\
\text { volume }\left(\mathrm{m}^{3} / \text { tree }\right)\end{array}$ & $\begin{array}{c}\text { Volume kayu } \\
\text { total }\left(\mathrm{m}^{3} / \mathrm{ph}\right) \\
\text { Total } \text { wood } \\
\text { volume }\left(\mathrm{m}^{3} / \text { tree }\right)\end{array}$ \\
\hline IRR 122 & 0,10 & 0,26 & $0,36(103)$ \\
IRR 123 & 0,11 & 0,27 & $0,38(109)$ \\
IRR 127 & 0,11 & 0,32 & $0,43(123)$ \\
IRR 129 & 0,15 & 0,32 & $0,47(134)$ \\
IRR 131 & 0,16 & 0,87 & $1,03(294)$ \\
IRR 132 & 0,15 & 0,36 & $0,51(146)$ \\
IRR 133 & 0,15 & 0,43 & $0,58(166)$ \\
IRR 134 & 0,14 & 0,44 & $0,58(166)$ \\
IRR 136 & 0,19 & 0,41 & $0,60(171)$ \\
IRR 137 & 0,14 & 0,35 & $0,49(140)$ \\
IRR 138 & 0,17 & 0,62 & $0,79(226)$ \\
IRR 139 & 0,11 & 0,24 & $0,35(100)$ \\
IRR 140 & 0,19 & 0,80 & $0,99(283)$ \\
IRR 141 & 0,07 & 0,18 & $0,25(71)$ \\
IRR 142 & 0,12 & 0,35 & $0,47(134)$ \\
IRR 143 & 0,15 & 0,32 & $0,47(134)$ \\
IRR 144 & 0,10 & 0,29 & $0,39(111)$ \\
PB 260 & 0,09 & 0,26 & $0,35(100)$ \\
\hline
\end{tabular}

kayu total yang lebih besar dibanding klon PB $260\left(0,35 \mathrm{~m}^{3} / \mathrm{ph}\right)$, kecuali IRR $141(0,25$ $\mathrm{m}^{3} / \mathrm{ph}$ ). Berdasarkan potensi volume kayu, klon IRR 131 dan IRR 140 tergolong jenis yang memiliki biomassa kayu paling besar, dengan potensi kayu log mencapai 0,16 $0,19 \mathrm{~m}^{3} / \mathrm{ph}$, kayu kanopi $0,80-0,87 \mathrm{~m}^{3} / \mathrm{ph}$ dan volume kayu total $0,99-1,03 \mathrm{~m}^{3} / \mathrm{ph}$.

\section{Potensi Produksi}

Data potensi produksi karet kering $\mathrm{g} / \mathrm{p} / \mathrm{s}$ dan $\mathrm{kg} / \mathrm{ha} /$ th klon IRR seri 120 - 140 selama delapan tahun penyadapan disajikan pada Tabel 3. Sebanyak dua klon memperlihatkan rata-rata potensi produksi 15 - 20\% lebih tinggi dari klon pembanding PB 260 (1.739 kg), yaitu IRR $132(2.088 \mathrm{~kg})$, IRR 133 (2006 kg). Klon-klon lainnya memiliki produksi berkisar 75 - 94\% dibanding klon PB 260. Dari tren produksi selama delapan tahun sadap, tampak beberapa klon memiliki produksi yang tinggi pada awal penyadapan (quick starter), namun mengalami penurunan pada penyadapan tahun berikutnya, sehingga total produksi menjadi rendah. Disamping itu terdapat dua klon yang tergolong jagur dan memiliki potensi produksi $\mathrm{kg} / \mathrm{ha} /$ th yang relatif sama dengan PB 260, yaitu IRR $131(1.638 \mathrm{~kg})$ dan IRR 140 $(1.610 \mathrm{~kg})$.

\section{Tebal Kulit dan Jaringan Pembuluh Lateks}

Ketebalan kulit murni memiliki pengaruh langsung terhadap kemudahan menyadap pohon karet serta potensi produksi lateks. Demikian juga jumlah ring (lingkar) dan diameter pembuluh lateks menjadi pertimbangan di dalam memilih klon yang memiliki potensi hasil lateks tinggi (high latex yielding clones). Dari beberapa hasil penelitian menunjukkan, bahwa variabel tebal kulit, jumlah ring dan diameter pembuluh lateks memberikan 
Tabel 3. Rata-rata potensi produksi karet kering klon IRR seri 120 - 140 Table 3. Average potency of dry rubber yield of clones IRR 120 - 140 series

\begin{tabular}{|c|c|c|c|c|c|c|c|c|c|c|}
\hline \multirow[t]{2}{*}{$\begin{array}{l}\text { Klon } \\
\text { Clones }\end{array}$} & \multicolumn{8}{|c|}{$\begin{array}{l}\text { Produksi rata-rata } \mathrm{g} / \mathrm{p} / \mathrm{s} \text { dan } \mathrm{kg} / \mathrm{ha} / \text { th per tahun sadap } \\
\text { Average yield } \mathrm{g} / \mathrm{t} / \mathrm{t} \text { and } \mathrm{kg} / \mathrm{ha} / \text { th per tapping years }\end{array}$} & \multirow[t]{2}{*}{$\begin{array}{c}\text { Rata-rata } \\
\text { Average }\end{array}$} & \multirow{2}{*}{$\begin{array}{c}\% \text { terhadap } \\
\text { PB } 260 \\
\% \text { of PB } 260\end{array}$} \\
\hline & 1 & 2 & 3 & 4 & 5 & 6 & 7 & 8 & & \\
\hline \multirow[t]{2}{*}{ IRR 122} & 27,4 & 32 & 36,5 & 31 & 51,5 & 33,5 & 31 & 27,5 & 33,8 & \\
\hline & 929 & 1.266 & 1.650 & 1.401 & 2.328 & 1.514 & 1.401 & 1.245 & 1.467 & 84 \\
\hline \multirow[t]{2}{*}{ IRR 123} & 36,2 & 31,3 & 32,5 & 34,5 & 44,6 & 35,3 & 40,6 & 33,6 & 36,1 & \\
\hline & 1.227 & 1.238 & 1.469 & 1.559 & 2.016 & 1.596 & 1.835 & 1.519 & 1.557 & 90 \\
\hline \multirow[t]{2}{*}{ IRR 127} & 30,5 & 29,8 & 33,4 & 37,1 & 51 & 29,7 & 29,6 & 27,7 & 33,6 & \\
\hline & 1.034 & 1.179 & 1.510 & 1.677 & 2.305 & 1.342 & 1.338 & 1.251 & 1.454 & 84 \\
\hline \multirow[t]{2}{*}{ IRR 129} & 32,2 & 275 & 306 & 22 & 488 & 30 2 & 29 & 27,2 & 309 & \\
\hline & 1.092 & 1.088 & 1.383 & 994 & 2.206 & 1.365 & 1.311 & 1.232 & 1.334 & 77 \\
\hline \multirow[t]{2}{*}{ IRR 131} & 20,2 & 38,4 & 35,6 & 34,3 & 43,8 & 45,3 & 41,9 & 40,3 & 37,5 & \\
\hline & 685 & 1.519 & 1.609 & 1.550 & 1.980 & 2.048 & 1.894 & 1.820 & 1.638 & 94 \\
\hline \multirow[t]{2}{*}{ IRR 132} & 40,1 & 47,7 & 45,3 & 42,9 & 56,4 & 58,9 & 48,9 & 45,4 & 48,2 & \\
\hline & 1.359 & 1.887 & 2.048 & 1.939 & 2.549 & 2.662 & 2.210 & 2.051 & 2.088 & 120 \\
\hline \multirow[t]{2}{*}{ IRR 133} & 32,9 & 50,7 & 40,4 & 43,8 & 53,6 & 55,2 & 48,1 & 44,9 & 46,2 & \\
\hline & 1.115 & 2.005 & 1.826 & 1.980 & 2.423 & 2.495 & 2.174 & 2.029 & 2.006 & 115 \\
\hline \multirow[t]{2}{*}{ IRR 134} & 22,6 & 29,6 & 32,9 & 29,4 & 38,5 & 26,7 & 31 & 29,7 & 30,1 & \\
\hline & 766 & 1.171 & 1.487 & 1.329 & 1.740 & 1.207 & 1.401 & 1.344 & 1.306 & 75 \\
\hline \multirow[t]{2}{*}{ IRR 136} & 29,2 & 32,4 & 39,2 & 31,1 & 38,4 & 32,1 & 43,9 & 34,5 & 35,1 & \\
\hline & 990 & 1.281 & 1.772 & 1.406 & 1.736 & 1.451 & 1.984 & 1.561 & 1.523 & 88 \\
\hline \multirow[t]{2}{*}{ IRR 137} & 33 & 39,2 & 34,8 & 37 & 42,4 & 23,1 & 27,9 & 39,9 & 34,7 & \\
\hline & 1.119 & 1.550 & 1.573 & 1.672 & 1.916 & 1.044 & 1.261 & 1.803 & 1.492 & 86 \\
\hline \multirow[t]{2}{*}{ IRR 138} & 19,2 & 20,2 & 29,5 & 31,5 & 38,3 & 37,7 & 36,9 & 50,0 & 31,9 & \\
\hline & 651 & 799 & 1.333 & 1.424 & 1.731 & 1.342 & 1.668 & 2.261 & 1.401 & 81 \\
\hline \multirow[t]{2}{*}{ IRR 139} & 37,5 & 34,7 & 27,4 & 32,8 & 47 & 29,2 & 31,1 & 29,2 & 33,6 & \\
\hline & 1.271 & 1.372 & 1.238 & 1.483 & 2.124 & 1.320 & 1.406 & 1.320 & 1.442 & 83 \\
\hline \multirow[t]{2}{*}{ IRR 140} & 24,1 & 35,2 & 34,4 & 32,4 & 40,3 & 46,9 & 43,4 & 38,6 & 36,9 & \\
\hline & 817 & 1.392 & 1.555 & 1.464 & 1.822 & 2.120 & 1.962 & 1.745 & 1.610 & 93 \\
\hline \multirow[t]{2}{*}{ IRR 141} & 32,2 & 48 & 31,5 & 35,7 & 43,1 & 23,6 & 26,6 & 22,3 & 32,9 & \\
\hline & 1.092 & 1.898 & 1.424 & 1.614 & 1.948 & 1.067 & 1.202 & 1.009 & 1.407 & 81 \\
\hline \multirow[t]{2}{*}{ IRR 142} & 30,1 & 32,6 & 34,4 & 31,4 & 43,2 & 31,1 & 34,6 & 30,9 & 33,5 & \\
\hline & 1.020 & 1.289 & 1.555 & 1.419 & 1.953 & 1.406 & 1.564 & 1.395 & 1.450 & 83 \\
\hline \multirow[t]{2}{*}{ IRR 143} & 27,8 & 33,4 & 32,1 & 29,1 & 44 & 27,1 & 37,4 & 35,2 & 33,3 & \\
\hline & 942 & 1.321 & 1.451 & 1.315 & 1.989 & 1.225 & 1.690 & 1.591 & 1.441 & 83 \\
\hline \multirow[t]{2}{*}{ IRR 144} & 23,7 & 31 & 34,3 & 30,5 & 43 & 27,9 & 31,1 & 39,5 & 32,6 & \\
\hline & 803 & 1.226 & 1.550 & 1.379 & 1.944 & 1.261 & 1.406 & 1.787 & 1.419 & 82 \\
\hline \multirow[t]{2}{*}{ PB 260} & 30,3 & 39,5 & 37,2 & 34,8 & 48,1 & 40,4 & 46,4 & 43,6 & 40,0 & \\
\hline & 1.027 & 1.562 & 1.681 & 1.573 & 2.174 & 1.826 & 2.097 & 1.971 & 1.739 & 100 \\
\hline
\end{tabular}


kontribusi yang nyata terhadap potensi produksi lateks pada tanaman karet (Gomez, 1980; Aidi-Daslin et al., 2008). Data pengamatan tebal kulit dan jaringan pembuluh lateks dapat dilihat pada Tabel 4. Variasi tebal kulit murni klon yang diuji berkisar 4,2 - 7,2 $\mathrm{mm}$. Klon yang memiliki kulit murni paling tebal adalah IRR $131(7,2$ $\mathrm{mm})$ menyusul IRR $132(6,7 \mathrm{~mm})$, IRR 136 (6,6 mm), IRR $133(6,5 \mathrm{~mm})$ dan IRR $140(6,0$ $\mathrm{mm})$ dibanding PB $260(5,8 \mathrm{~mm})$, sedangkan klon IRR lainnya berkisar 4,2 - 5,9 mm. Rata-rata jumlah pembuluh lateks bervariasi antara 4,2 - 10,5 ring. Klon yang memiliki jumlah ring pembuluh lateks tertinggi adalah IRR $132(10,5)$ menyusul IRR $136(10,0)$, IRR $133(9,5)$ dan IRR 140 $(9,0)$ dibanding dengan PB $260 \quad(8,2)$, sedangkan klon lainnya berkisar 4,2 - 8,2 ring. Kemudian klon yang memperlihatkan ukuran diameter pembuluh lateks tertinggi, masing-masing IRR $136(21,5 \mathrm{~m} \mu)$, IRR 140 (20,7 $\mathrm{m \mu})$, IRR $131(20,5 \mathrm{~m} \mu)$, IRR $132(19,5$ $\mathrm{m} \mu)$ dan IRR $133(19,8 \mathrm{~m} \mu)$ dibanding PB 260 $(17,8 \mathrm{~m} \mu)$, sedangkan klon IRR lainnya antara $11,2-16,0 \mathrm{m \mu}$.

\section{Fisiologi Aliran Lateks}

Sifat fisiologi aliran lateks menggambarkan kecepatan dan hambatan laju aliran lateks per satuan waktu, yang ditentukan oleh variabel indeks penyumbatan, kecepatan aliran, dan indeks produksi. Klon dengan aliran lateks yang lama dan indeks penyumbatan rendah, akan menghasilkan volume lateks yang lebih

Tabel 4. Tebal kulit dan jaringan pembuluh lateks klon karet IRR seri 120 - 140

Table 4. Bark thickness and latex vessel tissue of rubber clones IRR 120 - 140 series

\begin{tabular}{cccc}
\hline Klon & $\begin{array}{c}\text { Tebal kulit } \\
\text { murni } \\
\text { Virgin bark } \\
\text { thickness } \\
\text { (mm) }\end{array}$ & $\begin{array}{c}\text { Jumlah ring } \\
\text { pembuluh lateks } \\
\text { Number of latex } \\
\text { vessel rings }\end{array}$ & $\begin{array}{c}\text { Diameter } \\
\text { pembuluh lateks } \\
\text { Diameter of } \\
\text { latex vessel } \\
(\mathrm{m} \mu)\end{array}$ \\
\hline IRR 122 & $5,1(88)$ & $5,1(61)$ & $15,2(85)$ \\
IRR 123 & $4,2(72)$ & $4,2(51)$ & $11,2(63)$ \\
IRR 127 & $5,4(93)$ & $4,5(55)$ & $13,9(78)$ \\
IRR 129 & $4,7(81)$ & $4,5(55)$ & $11,8(66)$ \\
IRR 131 & $7,2(124)$ & $8,2(100)$ & $20,5(115)$ \\
IRR 132 & $6,7(116)$ & $10,5(128)$ & $19,5(110)$ \\
IRR 133 & $6,5(112)$ & $9,5(116)$ & $19,8(111)$ \\
IRR 134 & $6,0(103)$ & $5,0(61)$ & $14,1(79)$ \\
IRR 136 & $6,6(114)$ & $10,0(122)$ & $21,5(121)$ \\
IRR 137 & $5,9(102)$ & $6,2(76)$ & $14,5(81)$ \\
IRR 138 & $6,0(103)$ & $6,6(80)$ & $15,5(87)$ \\
IRR 139 & $5,2(90)$ & $5,3(65)$ & $14,9(84)$ \\
IRR 140 & $6,0(103)$ & $9,0(100)$ & $20,7(116)$ \\
IRR 141 & $4,2(72)$ & $4,7(57)$ & $11,5(65)$ \\
IRR 142 & $5,3(91)$ & $4,5(55)$ & $12,8(72)$ \\
IRR 143 & $6,3(109)$ & $7,5(91)$ & $16,0(90)$ \\
IRR 144 & $5,4(93)$ & $6,5(79)$ & $14,5(81)$ \\
PB 260 & $5,8(100)$ & $8,2(100)$ & $17,8(100)$ \\
\hline In) & &
\end{tabular}

Angka dalam kurung adalah persen terhadap klon PB 260

Figures in breakets are percentage of PB 260 clone 
besar, tetapi klon dengan indeks penyumbatan tinggi lebih respons terhadap stimulan (Southorn dan Gomez, 1970; Subronto dan Haris, 1977). Ketiga karakter tersebut menjadi variabel pendukung didalam memilih klon-klon karet penghasil lateks tinggi (Aidi-Daslin et al., 2008). Data hasil pengamatan fisiologi aliran lateks klonklon yang diuji disajikan pada Tabel 5.

Secara umum data pada Tabel 5 memperlihatkan kisaran indeks penyumbatan klon IRR 120 - 140 relatif sama antara $14,69-35,80 \%$ yang lebih tinggi dibanding PB 260 (7,43\%). Klon yang memiliki indeks penyumbatan tertinggi adalah IRR 134 (35,80\%) dan IRR 137 (30,02\%), sedangkan yang paling rendah terdapat pada klon IRR 141 (14,69\%) dan IRR 142 (19,57\%). Potensi hasil klon dengan produksi yang baik tetapi memiliki indeks penyumbatan tinggi, masih dapat dipacu jika disadap memakai stimulan. Kecepatan aliran lateks tertinggi terdapat pada klon IRR 136 (28,74 cc/menit) dibanding PB 260 (7,02 cc/menit), dan terendah pada klon IRR 129, IRR 141, IRR
142 bervariasi antara 9,18 - 9,84 cc/menit. Subronto dan Haris (1977) menyatakan bahwa kecepatan aliran lateks pada tanaman karet merupakan sifat fisiologis penting dalam menentukan variasi potensi hasil antar klon. Klon karet yang memiliki kecepatan aliran lateks yang tinggi diharapkan potensi produksinya juga tinggi. Dari variabel indeks produksi, terdapat enam klon dengan indeks produksi yang tinggi yaitu IRR132, IRR 133, IRR 136, IRR 140, IRR143 dan IRR 144 dengan kisaran $101,68-130,46 \%$.

\section{Karakteristik Sekunder}

Gangguan penyakit gugur daun Colletotrichum, Oidium, dan Corynespora sangat mempengaruhi produktivitas tanaman karet. Serangan berkelanjutan dalam jangka panjang dapat menurunkan produktivitas secara signifikan sampai mencapai $40 \%$ dan dapat menyebabkan kematian tanaman (Basuki et al., 1990). Oleh karena itu evaluasi klon pada tingkat

Tabel 5. Fisiologi aliran lateks klon karet IRR seri 120 - 140

Table 5. Latex flow physiology of rubber clones IRR 120 - 140 series

\begin{tabular}{cccc}
\hline Klon & $\begin{array}{c}\text { Indeks penyumbatan } \\
\text { Plugging index } \\
\text { Clones }\end{array}$ & $\begin{array}{c}\text { Kecepatan aliran } \\
\text { lateks } \\
\text { (cc/menit) }\end{array}$ & $\begin{array}{c}\text { Indeks produksi } \\
\text { Yield index } \\
(\text { clow } / \text { minute })\end{array}$ \\
\hline IRR 122 & 20,14 & 11,78 & 82,62 \\
IRR 123 & 21,99 & 11,88 & 67,78 \\
IRR 127 & 21,42 & 15,40 & 99,10 \\
IRR 129 & 22,89 & 9,84 & 67,04 \\
IRR 131 & 21,55 & 17,36 & 93,05 \\
IRR 132 & 20,91 & 21,98 & 130,46 \\
IRR 133 & 22,28 & 18,93 & 114,86 \\
IRR 134 & 35,80 & 17,90 & 93,88 \\
IRR 136 & 22,64 & 28,74 & 124,96 \\
IRR 137 & 30,02 & 19,42 & 89,52 \\
IRR 138 & 24,38 & 17,02 & 87,74 \\
IRR 139 & 21,16 & 14,52 & 93,55 \\
IRR 140 & 28,21 & 22,83 & 101,68 \\
IRR 141 & 14,69 & 9,19 & 85,60 \\
IRR 142 & 19,57 & 9,29 & 60,30 \\
IRR 143 & 20,01 & 18,39 & 123,55 \\
IRR 144 & 21,34 & 17,57 & 120,78 \\
PB 260 & 7,43 & 7,02 & 137,22
\end{tabular}


Tabel 6. Karakteristik sekunder klon karet IRR seri 120-140

Table 6. Secondary characteristics of rubber clones IRR 120-140 series

\begin{tabular}{|c|c|c|c|c|c|c|c|}
\hline \multirow{2}{*}{$\begin{array}{l}\text { Klon } \\
\text { Clones }\end{array}$} & \multicolumn{3}{|c|}{$\begin{array}{l}\text { Ketahanan penyakit } \\
\text { Disease resistance }\end{array}$} & \multicolumn{2}{|c|}{$\begin{array}{c}\text { Sifat latex } \\
\text { Latex characteristics }\end{array}$} & \multirow{2}{*}{$\begin{array}{l}\text { Tajuk } \\
\text { Canopy }\end{array}$} & \multirow{2}{*}{$\begin{array}{c}\text { Gugur daun } \\
\text { Wintering }\end{array}$} \\
\hline & Coll & Oid & Cory & $\begin{array}{l}\text { Warna } \\
\text { Colour }\end{array}$ & $\begin{array}{l}\text { Kemantapan } \\
\text { Stability }\end{array}$ & & \\
\hline IRR 122 & $\mathrm{AR}$ & $\mathrm{AR}$ & $\mathrm{R}$ & $\mathrm{P}$ & $\begin{array}{l}\text { stabil } \\
\text { stable }\end{array}$ & $\begin{array}{l}\text { rimbun } \\
\text { dense }\end{array}$ & $\begin{array}{l}\text { bertahap } \\
\text { gradual }\end{array}$ \\
\hline IRR 123 & $\mathrm{R}$ & $\mathrm{R}$ & $\mathrm{R}$ & $\mathrm{P}$ & $\begin{array}{l}\text { stabil } \\
\text { stable }\end{array}$ & $\begin{array}{l}\text { rimbun } \\
\text { dense }\end{array}$ & $\begin{array}{l}\text { bertahap } \\
\text { gradual }\end{array}$ \\
\hline IRR 127 & $\mathrm{AR}$ & $\mathrm{R}$ & $\mathrm{R}$ & $\mathrm{P}$ & $\begin{array}{l}\text { stabil } \\
\text { stable }\end{array}$ & $\begin{array}{l}\text { rimbun } \\
\text { dense }\end{array}$ & $\begin{array}{l}\text { bertahap } \\
\text { gradual }\end{array}$ \\
\hline IRR 129 & $\mathrm{AR}$ & $\mathrm{AR}$ & $\mathrm{R}$ & PK & $\begin{array}{l}\text { stabil } \\
\text { stable }\end{array}$ & $\begin{array}{l}\text { jarang } \\
\text { rare }\end{array}$ & $\begin{array}{l}\text { serentak } \\
\text { simultaneous }\end{array}$ \\
\hline IRR 131 & $\mathrm{AR}$ & $\mathrm{AR}$ & $\mathrm{R}$ & PK & $\begin{array}{l}\text { stabil } \\
\text { stable }\end{array}$ & $\begin{array}{l}\text { sedang } \\
\text { medium }\end{array}$ & $\begin{array}{l}\text { serentak } \\
\text { simultaneous }\end{array}$ \\
\hline IRR 132 & $\mathrm{R}$ & $\mathrm{R}$ & $\mathrm{R}$ & $\mathrm{P}$ & $\begin{array}{l}\text { stabil } \\
\text { stable }\end{array}$ & $\begin{array}{l}\text { sedang } \\
\text { medium }\end{array}$ & $\begin{array}{l}\text { bertahap } \\
\text { gradual }\end{array}$ \\
\hline IRR 133 & $\mathrm{R}$ & $\mathrm{R}$ & $\mathrm{R}$ & PK & $\begin{array}{l}\text { stabil } \\
\text { stable }\end{array}$ & $\begin{array}{l}\text { sedang } \\
\text { medium }\end{array}$ & $\begin{array}{l}\text { serentak } \\
\text { simultaneous }\end{array}$ \\
\hline IRR 134 & $\mathrm{AR}$ & $\mathrm{AR}$ & $\mathrm{R}$ & $\mathrm{P}$ & $\begin{array}{l}\text { stabil } \\
\text { stable }\end{array}$ & $\begin{array}{l}\text { jarang } \\
\text { rare }\end{array}$ & $\begin{array}{l}\text { serentak } \\
\text { simultaneous }\end{array}$ \\
\hline IRR 136 & $\mathrm{R}$ & $\mathrm{AR}$ & $\mathrm{R}$ & PK & $\begin{array}{l}\text { tidak stabil } \\
\text { not-stable }\end{array}$ & $\begin{array}{l}\text { sedang } \\
\text { medium }\end{array}$ & $\begin{array}{l}\text { bertahAp } \\
\text { gradual }\end{array}$ \\
\hline IRR 137 & $\mathrm{AR}$ & $\mathrm{AR}$ & $\mathrm{R}$ & PK & $\begin{array}{l}\text { stabil } \\
\text { stable }\end{array}$ & $\begin{array}{l}\text { jarang } \\
\text { rare }\end{array}$ & $\begin{array}{l}\text { bertahap } \\
\text { gradual }\end{array}$ \\
\hline IRR 138 & $\mathrm{AR}$ & $\mathrm{AR}$ & $\mathrm{R}$ & $\mathrm{P}$ & $\begin{array}{l}\text { stabil } \\
\text { stable }\end{array}$ & $\begin{array}{l}\text { rimbun } \\
\text { dense }\end{array}$ & $\begin{array}{l}\text { serentak } \\
\text { simultaneous }\end{array}$ \\
\hline IRR 139 & $\mathrm{R}$ & $\mathrm{AR}$ & $\mathrm{R}$ & PK & $\begin{array}{l}\text { stabil } \\
\text { stable }\end{array}$ & $\begin{array}{l}\text { sedang } \\
\text { medium }\end{array}$ & $\begin{array}{l}\text { bertahap } \\
\text { gradual }\end{array}$ \\
\hline IRR 140 & $\mathrm{R}$ & $\mathrm{AR}$ & $\mathrm{R}$ & PK & $\begin{array}{l}\text { stabil } \\
\text { stable }\end{array}$ & $\begin{array}{l}\text { sedang } \\
\text { medium }\end{array}$ & $\begin{array}{l}\text { bertahap } \\
\text { gradual }\end{array}$ \\
\hline IRR 141 & $\mathrm{R}$ & $\mathrm{R}$ & $\mathrm{R}$ & $\mathrm{P}$ & $\begin{array}{l}\text { stabil } \\
\text { stable }\end{array}$ & $\begin{array}{l}\text { rimbun } \\
\text { dense }\end{array}$ & $\begin{array}{l}\text { bertahap } \\
\text { gradual }\end{array}$ \\
\hline IRR 142 & $\mathrm{R}$ & $\mathrm{R}$ & $\mathrm{R}$ & $\mathrm{P}$ & $\begin{array}{l}\text { tidak stabil } \\
\text { not-stable }\end{array}$ & $\begin{array}{l}\text { jarang } \\
\text { rare }\end{array}$ & $\begin{array}{l}\text { bertahap } \\
\text { gradual }\end{array}$ \\
\hline IRR 143 & $\mathrm{R}$ & $\mathrm{AR}$ & $\mathrm{R}$ & $\mathrm{P}$ & $\begin{array}{l}\text { stabil } \\
\text { stable }\end{array}$ & $\begin{array}{l}\text { rimbun } \\
\text { dense }\end{array}$ & $\begin{array}{l}\text { serentak } \\
\text { simultaneous }\end{array}$ \\
\hline IRR 144 & $\mathrm{AR}$ & $\mathrm{AR}$ & $\mathrm{R}$ & PK & $\begin{array}{l}\text { stabil } \\
\text { stable }\end{array}$ & $\begin{array}{l}\text { rimbun } \\
\text { dense }\end{array}$ & $\begin{array}{l}\text { serentak } \\
\text { simultaneous }\end{array}$ \\
\hline PB 260 & $\mathrm{R}$ & $\mathrm{R}$ & $\mathrm{R}$ & PK & $\begin{array}{l}\text { stabil } \\
\text { stable }\end{array}$ & $\begin{array}{l}\text { sedang } \\
\text { medium }\end{array}$ & $\begin{array}{l}\text { bertahap } \\
\text { gradual }\end{array}$ \\
\hline
\end{tabular}

Coll $=$ Colletotrichum gloeosporioides $\quad$ Oid $=$ Oidium heveae $\quad$ Cory $=$ Corynespora cassiicola

$\mathrm{AR}=$ agak resisten (moderately resistant) $\mathrm{R}=$ resisten (resistant),

$\mathrm{P}=$ putih (white) $\mathrm{PK}=$ putih kekuningan (yellowish white) 
laboratorium maupun lapangan sangat perlu dilakukan untuk mengetahui ketahanan genetik klon terhadap penyakit gugur daun. Evaluasi pada tingkat lapangan memperlihatkan ketahanan klon yang diuji terhadap serangan penyakit gugur daun Colletotrichum dan Oidium tergolong moderat resisten sampai dengan resisten serta terhadap penyakit gugur daun Corynespora tergolong resisten. Dari kualitas lateks, klon IRR 136 dan IRR 142 menghasilkan mutu lateks yang tidak stabil (cepat menggumpal), sedangkan klon lainnya tergolong stabil. Karakteristik klon secara lengkap disajikan pada Tabel 6 .

\section{Evaluasi Potensi Klon}

Berdasarkan potensi produksi karet kering serta karakter pendukung lainnya, terdapat dua klon yang memiliki penampilan terbaik yaitu klon IRR 132 dan IRR 133 yang potensial dikembangkan untuk penanaman komersial. Kedua klon tersebut memperlihatkan berbagai karakter yang lebih baik dibanding klon PB 260. Rata-rata produksi karet kering $\mathrm{kg} / \mathrm{ha} /$ th $\mathrm{klon}$ IRR 132 dan IRR 133 masing-masing $2.088 \mathrm{~kg}$ dan $2.006 \mathrm{~kg}$ dibanding PB 260 (1.739 kg). Pertumbuhan kedua klon tersebut tergolong moderat, mencapai rata-rata lilit batang pada umur empat tahun antara 42,8 - 43,6 cm dengan potensi volume kayu 0,51 - 0,58 $\mathrm{m}^{3} / \mathrm{ph}$ serta tergolong resisten terhadap penyakit gugur daun Colletotrichum, Oidium, dan Corynespora.

Dilihat dari karakter sekunder lainnya, secara dominan klon IRR 132 dan IRR 133 memperlihatkan potensi keunggulan yang lebih baik daripada klon pembanding PB 260. Dari karakter indeks penyumbatan, kedua klon tersebut lebih respon terhadap stimulan, sehingga penyadapan dengan menggunakan stimulan lebih meningkatkan potensi hasil lateks. Karakteristik lengkap klon IRR 132 dan IRR 133 disajikan pada Tabel 7 . Klon yang

Tabel 7. Karakteristik klon terpilih IRR 132 dan IRR 133 dibanding PB 260

Table 7. Characteristics of selected clones of IRR 132 and IRR 133 compared with PB 260

\begin{tabular}{|c|c|c|c|c|}
\hline No & $\begin{array}{l}\text { Variabel } \\
\text { Variables }\end{array}$ & IRR 132 & IRR 133 & PB 260 \\
\hline 1 & $\begin{array}{l}\text { Lilit batang umur empat tahun }(\mathrm{cm}) \\
\text { Girth at four years old }(\mathrm{cm})\end{array}$ & 43,6 & 42,8 & 41,7 \\
\hline 2 & $\begin{array}{l}\text { Tebal kulit murni }(\mathrm{mm}) \\
\text { Bark thickness }(\mathrm{mm})\end{array}$ & 6,7 & 6,5 & 5,8 \\
\hline 3 & $\begin{array}{l}\text { Laju pertumbuhan lilit batang TBM }(\mathrm{cm} / \mathrm{th}) \\
\text { Girth increasing on immature }(\mathrm{cm} / \mathrm{yr})\end{array}$ & 10,9 & 7,1 & 8,4 \\
\hline 4 & $\begin{array}{l}\text { Laju pertumbuhan lilit batang TM }(\mathrm{cm} / \mathrm{th}) \\
\text { Girth increasing on mature }(\mathrm{cm} / \mathrm{yr})\end{array}$ & 3,0 & 3,8 & 3,3 \\
\hline 5 & $\begin{array}{l}\text { Volume kayu total }\left(\mathrm{m}^{3} / \mathrm{ph}\right) \\
\text { Total wood volume }\left(\mathrm{m}^{3} / \text { tree }\right)\end{array}$ & 0,51 & 0,58 & 0,35 \\
\hline 6 & $\begin{array}{l}\text { Jumlah ring pembuluh lateks } \\
\text { Number of latex vessel rings }\end{array}$ & 10,5 & 9,5 & 8,2 \\
\hline 7 & $\begin{array}{l}\text { Diameter pembuluh lateks }(\mathrm{m} \mu) \\
\text { Diameter of latex vessels }(m \mu)\end{array}$ & 19,5 & 19,8 & 17,8 \\
\hline 8 & $\begin{array}{l}\text { Indeks penyumbatan (\%) } \\
\text { Plugging index (\%) }\end{array}$ & 20,91 & 22,28 & 7,43 \\
\hline 9 & $\begin{array}{l}\text { Kecepatan aliran lateks (cc/menit) } \\
\text { Latex flow rate (cc/minute) }\end{array}$ & 21,98 & 18,93 & 7,02 \\
\hline 10 & $\begin{array}{l}\text { Indeks produksi (\%) } \\
\text { Yield index (\%) }\end{array}$ & 130,46 & 114,86 & 137,22 \\
\hline 11 & $\begin{array}{l}\text { Rata-rata produksi } 8 \text { tahun sadap }(\mathrm{kg} / \mathrm{ha} / \mathrm{th}) \\
\text { Mean yield of eight tapping years }(\mathrm{kg} / \mathrm{ha} / \mathrm{yr})\end{array}$ & 2.088 & 2.006 & 1.739 \\
\hline
\end{tabular}


memiliki potensi volume kayu total tertinggi adalah IRR 131 dan IRR 140 berkisar 0,99$1,03 \mathrm{~m}^{3} / \mathrm{ph}$ ), dengan rata-rata produksi karet kering $\mathrm{kg} / \mathrm{ha} /$ th antara $1.610-1.638$ kg. Kedua klon tersebut tergolong paling jagur, sehingga sesuai dikembangkan sebagai klon penghasil lateks dan kayu.

\section{KESIMPULAN}

Dari hasil evaluasi uji lanjutan klon harapan IRR seri 120-140 diperoleh dua klon yang memiliki potensi dikembangkan sebagai klon unggul penghasil lateks yaitu klon IRR 132 dan IRR 133 dan dua klon sebagai penghasil lateks-kayu yaitu IRR 131 dan IRR 140. Potensi keunggulan IRR 132 dan IRR 133 memiliki produksi karet kering $\mathrm{kg} / \mathrm{ha} /$ th selama delapan tahun penyadapan masing-masing $2.088 \mathrm{~kg}$ dan $2.006 \mathrm{~kg}$, lilit batang pada umur empat tahun berkisar 42,8 - 43,6 cm dengan pertambahan sebelum penyadapan $7,1-10,9 \mathrm{~cm} /$ th dan setelah penyadapan $3,0-3,8 \mathrm{~cm} /$ th serta tebal kulit murni berkisar 6,5 - 6,7 mm serta tergolong moderat resisten sampai dengan resisten terhadap penyakit gugur daun Colletotrichum, Oidium, dan Corynespora. Klon IRR 131 dan IRR 140 memiliki potensi volume kayu total yang tinggi berkisar 0,99 $1,03 \mathrm{~m}^{3} / \mathrm{ph}$ dengan rata-rata produksi karet kering $\mathrm{kg} / \mathrm{ha} / \mathrm{th}$ antara $1.610-1.638 \mathrm{~kg}$.

\section{DAFTAR PUSTAKA}

Aidi-Daslin. 2005. Kemajuan pemuliaan dan seleksi dalam menghasilkan kultivar karet unggul. Pros. Lok. Nas. Pemuliaan Tanaman Karet 2005, 2637.

Aidi-Daslin, S. Woelan, M. Lasminingsih dan H. Hadi. 2009. Kemajuan pemuliaan dan seleksi tanaman karet di Indonesia. Pros. Lok. Nas. Pemuliaan Tanaman Karet 2005, 50-59.

Aidi-Daslin, Sayurandi dan S.Woelan. 2008. Keragaman genetik, heritabilitas dan korelasi berbagai karakter dengan hasil pada tanaman karet. J. Penel. Karet, 26(1), 1-9.
Basuki, S. Pawirosoemardjo, U. Nasution, Sutardi, W.Sinulingga dan A. Situmorang. 1990. Penyakit gugur daun Colletotrichum pada tanaman karet di Indonesia. Potensi, Penyebaran dan Penanggulangannya. Pros. Lok. Nas. Pemuliaan Tanaman Karet 1990, 268-295.

Gomez, J., R. Narayanan, and K. T. Chen. 1972. Some structural factors affecting the productivity of Hevea brasiliensis: Quantitative determination of laticiferous tissue. J. Rub. Res. Inst. Malaya, 23 (3), 193 - 203.

Gomez, J. B. 1980. Anatomy and ultracytology related to breeding of Hevea. RRIM Hevea Breeding Course, 2-18.

Milford, G. F. J., E. C. Paardekooper, C. Y. Ho. 1969. Latex vessel plugging; its importance to yield and clonal behavior. J. Rubb. Res. of Malaya, 21 (2), 274-282.

Subronto dan A. Harris. 1977. Indeks aliran sebagai parameter fisiologi penduga produksi lateks. Bull Perkaretan, 8(1), 33-41.

Southorn, W. A. and J. B. Gomez. 1970. Latex flow studies VII. Influence of length of tapping cut on latex flow pattern. J. Rubb. Ress. Inst. Malaysia, 23(1), 15-21.

Suhendry, I. 2002. Klon karet unggul harapan penghasil lateks-kayu dari hasil pengujian pendahuluan (Hasil Silang 1985-1989 pada UP/01/93). Indonesian J. Nat. Rubb. Res. 20 (13), 11-29.

Wan Razali Mohd, R. Maidin, A. Surjan and J. M. Zain. 1983. Double entry volume table equations for source RRIM 600 series clone of rubber.The Malaysian Forester, 46(1), 46-59.

Woelan, S., Aidi-Daslin, I. Suhendry, dan M. Lasminingsih. 2005. Evaluasi keragaan klon karet IRR seri 100 dan 200. Pros. Lok. Nas. Pemuliaan Tanaman. 